\title{
Developing Interactive E-Book as a Learning Resource for Seventh-Grade Junior High School Students
}

\author{
Aufal Hadaya \\ Departement of Educational Technology \\ Sebelas Maret University \\ Surakarta, Indonesia \\ tp11040.aufalhadaya@gmail.com
}

\author{
Sunardi \\ Departement of Educational Technology \\ Sebelas Maret University \\ Surakarta, Indonesia \\ Asrowi \\ Departement of Educational Technology \\ Sebelas Maret University \\ Surakarta, Indonesia
}

\begin{abstract}
The learning process in the 21st century is required to utilize technology. One trend of learning in the digital age is the use of an interactive e-book as a learning resource. This study aims to determine the advisability of an interactive e-book on history matter for a seventh-grade student as a learning resource for social studies subject. This research uses a research and development method with the ADDIE development model; the steps are analysis, design, development, implementation, evaluation. The product advisability test results show that the ebook has very good quality and deserve to be used as a learning resource based on the validation results of media experts and material experts, as well as user validation. Validation result of media experts showed a score of 4.67 with a very good category, validation result of material experts obtained a score of 4.26 with very good category, and user validation results obtained an average score of 4.48 with a very good category. Thus, the e-book is declared viable as a learning resource for learning on a social studies subject.
\end{abstract}

Keywords-e-book; interactive; learning resources; social studies subject.

\section{INTRODUCTION}

In this digital era, some schools have implemented technology-based learning, for example with the use of gadgets as a medium in learning and the use of e-learning platform to support web-based learning (web-based learning). Some schools, especially in urban areas, have provided various tools to optimize technology-based learning, such as internet connection, LCD projector, computer, etc. Not only relying on school facilities, students who already have gadgets like laptops are also allowed to bring them to school to support their learning.

The entry of information and communication technology in the field of education has indirectly changed the educational demands from teacher-centered-learning into student- centered-learning. Therefore, the learning principles used today are also transformed. Some of the principles of learning that have been practiced today are: (1) from students as they are told to find out; (2) from teachers as the only source of learning to learn from a variety of learning resources; (3) learning taking place at home, at school, and in the community; and (4) utilization of information and communication technology to improve the efficiency and effectiveness of learning [1]. The existence of the principles of learning above has demanded that today's teachers have the competence to be able to create effective, efficient and fun learning. Teachers are not only required to have mastery of learning materials but also to carry out learning by utilizing technology. Mastery of these technologies can be implemented on the use of a medium in learning. The use of media in the learning process will be able to generate new desires and interests, generate motivation and stimulation of learning activities, and have a psychological influence on students. Media can also be useful for generating passion for learning, enabling students to learn independently according to their interests and abilities [2]. Therefore, the ability of educators in developing instructional media becomes one of the determinants of student learning success.

Unfortunately, today's teachers and students have been in different eras. If students today have become part of the digital natives group, the teacher becomes a digital immigrant that is a generation born in an era that has not been exposed to technology. It can be said that the teacher is currently in transition to the digital age, thus it certainly takes more time to master it. This is why some teachers have not been able to optimize the use of technology in learning. As happens in the seventh-grade social studies subject, teachers still rely on lecture methods to deliver the material and learning more utilizes conventional printed books with a thickness of $2 \mathrm{~cm}$ than using instructional media. Garrison \& Vaughan [3] states that students in the digital age are not satisfied with the 
conventional learning format. Students tend to be bored if they just listen to the lectures from the teacher, and learning will become ineffective and conducive. Therefore, it takes an interesting instructional media so that students do not feel bored and have high learning interest. Essentially, the teachers have started to use instructional media such as PowerPoint media. Unfortunately, the use of this medium is not optimal; the teacher only displays the text on the PowerPoint that is displayed on the screen projector. When combined with lecture methods, the use of this medium is not yet able to arouse students' interest to learn. This is because students are not directly involved in using technology, thus they just listen to the teachers and view the media on the projector screen.

According to the demands of this digital era, where students are required to be technologically literate, the use of educational technology should not only involve teachers but also students. The use of PowerPoint media in the class does not support students to explore the media itself. There are many media that can be utilized by teachers other than PowerPoint media, such as film/movies, instructional videos, interactive multimedia, educational games, e-books, etc. One of the media sources that can be utilized by teachers for conventional learning as well as for self-learning students is an e-book. An e-book can be downloaded instantly and then read on an electronic tablet or even a mobile phone [4]. In some countries, e-books have become a new trend. Many publishers produced books only in an electronic format or created an electronic version of their printed books. In Indonesia, the government has also published e-books for students called Buku Sekolah Elektronik (BSE). Unfortunately, BSE is still limited to text and images. This is certainly not much different from conventional print books that tend to be static and less attractive. An interactive e-book is a book in digital format that integrates with video, audio, and interactive learning exercises so that students can measure their cognitive abilities in the mastery of learning materials. According to Smaldino, Lowther, and Russell [5] e-books can convey information in an interesting and interactive methods, which can involve learning activities as well as exercise questions to check students' understanding of the material when they read it.

Yaya [6] mentions some of the benefits of e-books in school media services such as: 1) Accessibility of information, e-book improves access to information easily and quickly in obtaining educational materials; 2) Save time, because the reader can get the required material in a short time; 3) Improve reading habits; 4) Cost effectiveness; 5) Space conservation, with digitization, where more space will be preserved because it requires less space for the installation and operation of ebooks and accessories; 6) Portability, where an e-book can be used anywhere and anytime only by using a handheld device; and 7) There is no physical limit, because e-book users do not need to visit the library or bookstore physically. The use of ebooks for learning feels appropriate to the development of education in the digital era, therefore the development of an interactive e-book as a learning source in social studies subject for seventh-grade junior high school students was conducted.

\section{METHOD}

The method in this study is research and development ( $\mathrm{R}$ and D). According to Soenarto [7], research and development is the research done by practitioners to produce products that can be used to improve the quality of performance or solve problems that occur in the workplace. The product development procedure in this research is using the ADDIE model (Analysis, Design, Development, Implementation, and Evaluation). However, this study will only be discussed three steps i.e. Analysis, Design, Development.

Data were collected by questionnaires which could be divided into 3 types, for experts on matter, experts on media, and students as users. Media experts provide an assessment of the display aspect, presentation of the content, material support, and multimedia elements. The matter experts will provide an assessment of aspects of the content, presentation of the content and language aspects, while students provide assessments related to display media, presentation of content, and product usability. A total of 31 seventh-grade students have validated the interactive e-book. Of the 31 students, 3 students participated in a one-to-one trial, 9 students participated in a small group trial and 20 students participated in a field trial. The data obtained in this study were quantitative. The quantitative data were then converted into qualitative using scale 5 as follows.

TABLE I.

CONVERSION OF QUANTITATIVE INTO QUALITATIVE DATA

\begin{tabular}{|c|c|c|}
\hline Interval Score & Score & Category \\
\hline $\mathrm{X}>4,21$ & 5 & Very Good \\
\hline $3,40<\mathrm{X} \leq 4,21$ & 4 & Good \\
\hline $2,60<\mathrm{X} \leq 3,40$ & 3 & Fair \\
\hline $1,79<\mathrm{X} \leq 2,60$ & 2 & Poor \\
\hline $\mathrm{X} \leq 1,79$ & 1 & Very poor \\
\hline
\end{tabular}

\section{RESUlT AND DisCUSSION}

This research is divided into three main steps, i.e. (1) Analysis, (2) Design, and (3) Development.

\section{A. Analysis}

The analysis stage is important because the results of the analysis will serve as guidelines for the interests of product development. A preliminary study was conducted to find out the problems and the right solutions to the problem. Preliminary study was conducted using survey method to 64 respondents. The results of the survey found that 1) the implementation of social studies learning is still carried out conventionally, teachers only use lecture method, question and answer, and assignment, especially on historical material; 2) Teachers still rely on textbooks and almost never use instructional media as an intermediary for the delivery of material; and 3) students have become part of a digital generation that is dissatisfied with conventional learning. 


\section{B. Design}

Based on the result of analysis, students need an interesting instructional media so that they do not feel bored during the process of learning in the classroom and need more exercise questions at the end of learning activities because a textbook does not provide much exercise to measure their understanding.

The design of the e-book contains concept maps, competency pages, learning objectives pages, materials with pictures and instructional videos, summary, exercise, and glossary. Because students need more exercises to help them measure cognitive abilities, then exercises are made with three types of exercise i.e. multiple choices, true-false quiz, and stuffing. Each type of exercise will show the score of a student's answers.

\section{Development}

The third stage is the development; at this stage the e-book began to be produced in accordance with the results of the design. After the production process, the e-book will be validated by an expert on media, an expert on matter and students as a user.

- Creating e-book. The process of making e-books begins with collecting reading material, pictures, and video. After all the ingredients have been collected, the e-book begins. The e-book is created using the Adobe Acrobat DC application, the output of the e-book is a PDF file (Portable Document Format). Many e-books in PDF format are only composed of text and images, even though the PDF format can also support interactive content such as video and an interactive quiz. Therefore, this e-book is accompanied by learning videos and exercise/quiz so that students can explore the material and know the level of achievement of their learning outcomes.

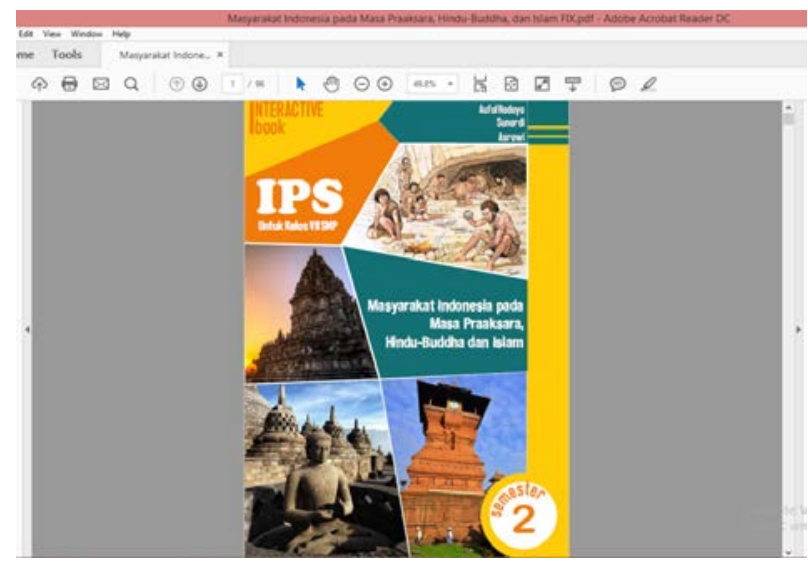

Fig. 1. Display of cover e-book

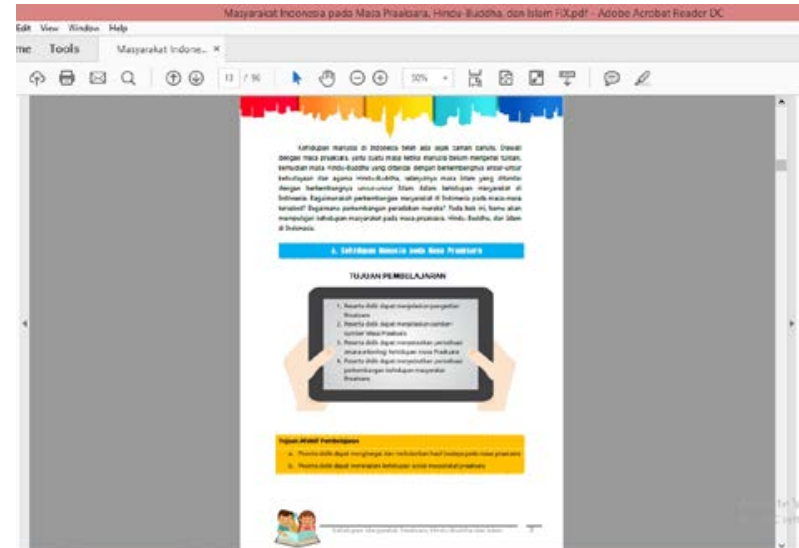

Fig. 2. Display of learning objectives pages

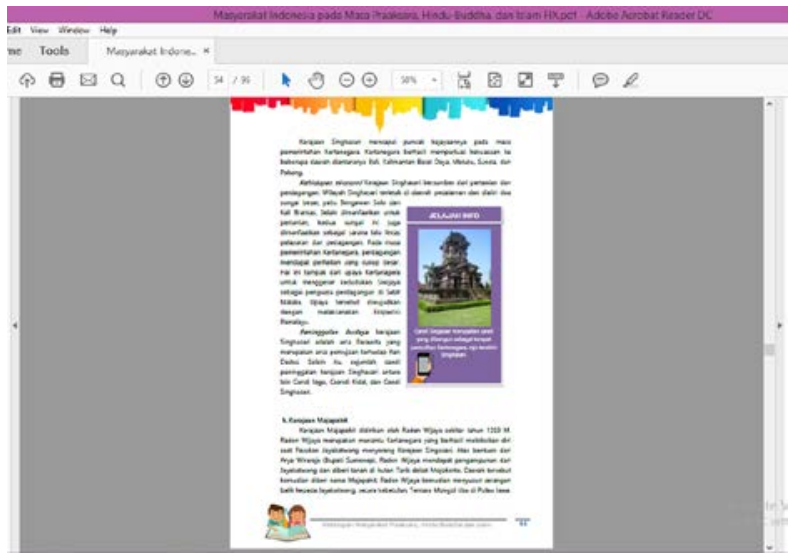

Fig. 3. Display of content with picture support

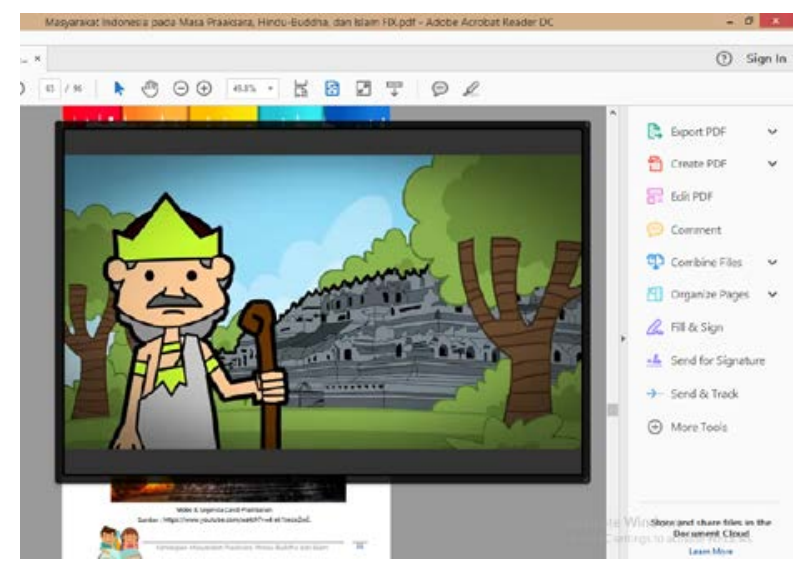

Fig. 4. Display of instructional video when the video is playing 


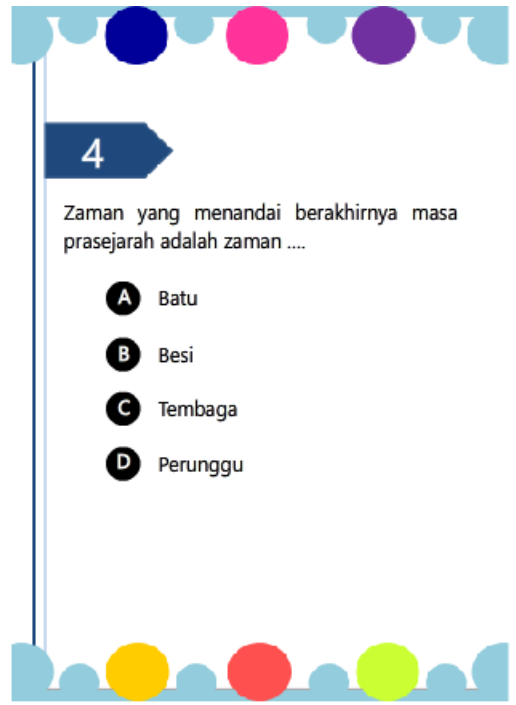

Fig. 5. Display of multiple choices exercise

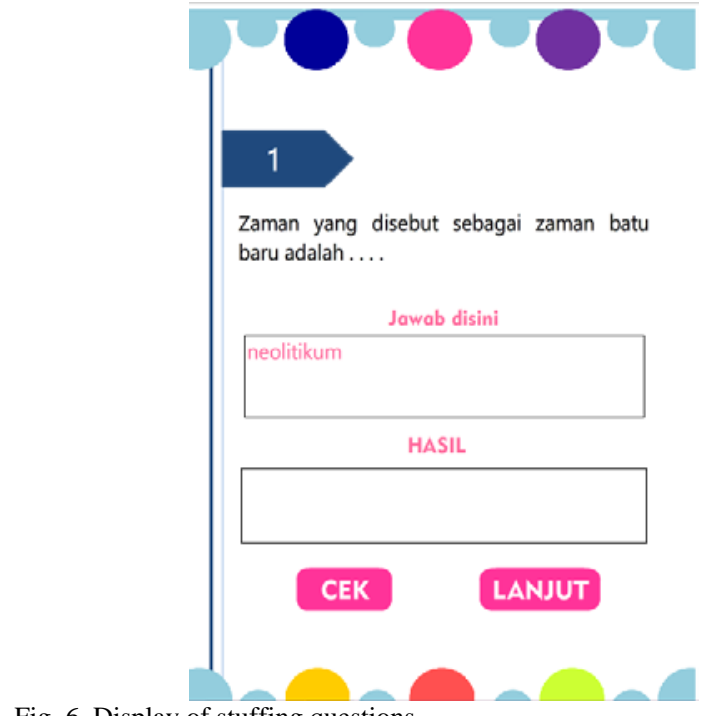

Fig. 6. Display of stuffing questions

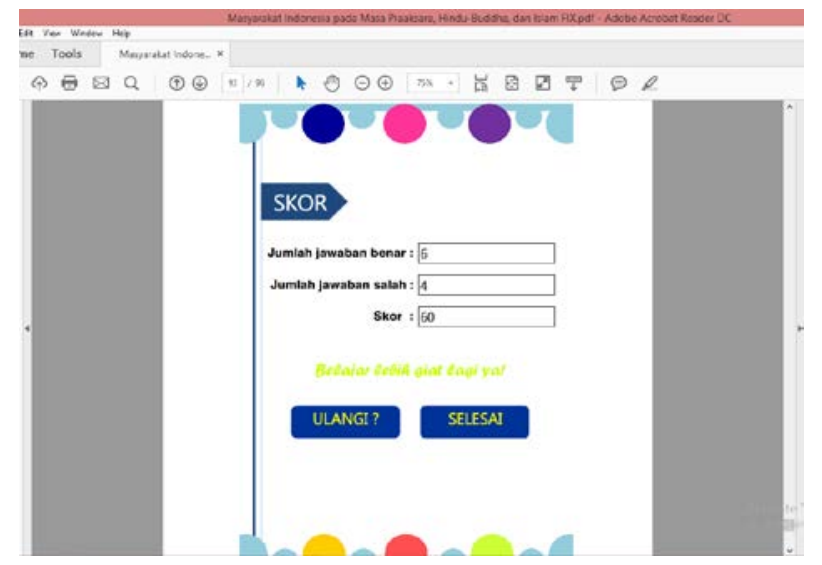

Fig. 7. Display of score answers students

- Expert Validation. Expert validation was carried out by two media experts and three material experts. Expert validation results are presented in Table 2 and Table 3.
TABLE II. EXPERT MATERIAL VALIDATION RESULTS

\begin{tabular}{|c|c|c|c|c|c|}
\hline \multirow{2}{*}{$\begin{array}{c}\text { Aspect of } \\
\text { assessment }\end{array}$} & \multicolumn{3}{|c|}{ Material Expert } & \multirow{2}{*}{$\begin{array}{c}\text { Average } \\
\text { of each } \\
\text { aspect }\end{array}$} & \multirow{2}{*}{$\begin{array}{c}\text { Categ } \\
\text { ories }\end{array}$} \\
\hline & I & II & III & & \\
\hline Content & 4.63 & 4.00 & 4.38 & 4.33 & $\begin{array}{l}\text { Very } \\
\text { Good }\end{array}$ \\
\hline $\begin{array}{c}\text { Presentation } \\
\text { of material }\end{array}$ & 4.88 & 4.50 & 3.88 & 4.42 & $\begin{array}{l}\text { Very } \\
\text { Good }\end{array}$ \\
\hline Language & 4.75 & 4.00 & 3.33 & 4.03 & Good \\
\hline Average & 4.75 & 4.17 & 3.86 & 4.26 & $\begin{array}{l}\text { Very } \\
\text { Good }\end{array}$ \\
\hline
\end{tabular}

Based on Table 2, obtained the average assessment on the content feasibility aspects of 4.33 with the criteria of excellent eligibility, presentation aspects of the material obtained an average of 4.42 with the criteria of excellent eligibility and language aspects obtained an average of 4,03 with good eligibility. The result of the overall aspect is 4.26 . Thus, it can be concluded that the interactive e-book for social studies subject from material aspects expressed very feasible use.

TABLE III. EXPERT MEDIA VALIDATION RESUlTS

\begin{tabular}{|l|c|c|c|c|}
\hline \multirow{2}{*}{$\begin{array}{c}\text { Aspect of } \\
\text { assessment }\end{array}$} & \multicolumn{2}{|c|}{$\begin{array}{c}\text { Media } \\
\text { Expert }\end{array}$} & $\begin{array}{c}\text { Average } \\
\text { of each } \\
\text { aspect }\end{array}$ & Categories \\
\cline { 2 - 5 } & I & II & \\
\hline $\begin{array}{l}\text { Learning } \\
\text { instructions }\end{array}$ & 5.00 & 5.00 & 5.00 & Very Good \\
\hline $\begin{array}{l}\text { Cover } \\
\text { design }\end{array}$ & 5.00 & 3.75 & 4.38 & Very Good \\
\hline $\begin{array}{l}\text { Content } \\
\text { Presentation }\end{array}$ & 4.90 & 4.40 & 4.65 & Very Good \\
\hline $\begin{array}{l}\text { Material } \\
\text { Support }\end{array}$ & 4.80 & 4.30 & 4.55 & Very Good \\
\hline $\begin{array}{l}\text { Multimedia } \\
\text { Principles }\end{array}$ & 4.83 & 4.67 & 4.75 & Very Good \\
\hline Average & $\mathbf{4 . 9 1}$ & $\mathbf{4 . 4 2}$ & $\mathbf{4 . 6 7}$ & Very Good \\
\hline
\end{tabular}

Based on Table 3 we can see the average assessment of learning instructions of 5.00 with excellent eligibility, cover design obtained an average of 4.38 with criteria is excellent eligibility, content presentation aspect of 4.65 with excellent eligibility, and material support of 4.55 with excellent eligibility criteria and the valuation of multimedia principles obtained an average of 4.75 with excellent eligibility criteria. The results of the overall aspect obtained an average value of 4.67. Thus, it can be concluded that the interactive e-book for social studies subject from the aspect of media is declared as very feasible to use.

- User Validation. User validation is performed through three stages: One-To-One Trial, Small Group Trial and Field Trial. 
TABLE IV. USER VALIDATION RESULTS

\begin{tabular}{|l|c|c|c|c|c|}
\hline $\begin{array}{c}\text { User } \\
\text { validation }\end{array}$ & N & $\begin{array}{c}\text { Display } \\
\text { of } \\
\text { e-book }\end{array}$ & $\begin{array}{c}\text { Present- } \\
\text { ation of } \\
\text { material }\end{array}$ & $\begin{array}{c}\text { Bene- } \\
\text { fit }\end{array}$ & $\begin{array}{c}\text { Ave- } \\
\text { rage }\end{array}$ \\
\hline $\begin{array}{l}\text { One-to-One } \\
\text { Trial }\end{array}$ & 3 & 4.13 & 4.54 & 4.59 & 4.42 \\
\hline $\begin{array}{l}\text { Small Group } \\
\text { Trial }\end{array}$ & 9 & 4.39 & 4.49 & 4.50 & 4.46 \\
\hline Field Trial & 20 & 4.46 & 4.61 & 4.59 & 4.55 \\
\hline $\begin{array}{l}\text { Average of each } \\
\text { aspect }\end{array}$ & 4.33 & 4.55 & 4.56 & 4.48 \\
\hline Categories & $\begin{array}{c}\text { Very } \\
\text { Good }\end{array}$ & $\begin{array}{c}\text { Very } \\
\text { Good }\end{array}$ & $\begin{array}{c}\text { Very } \\
\text { Good }\end{array}$ & $\begin{array}{l}\text { Very } \\
\text { Good }\end{array}$ \\
\hline
\end{tabular}

Based on Table 4 it was obtained that the average assessment on one-to-one trial is 4.13 in the aspect of the display design, 4.54 on aspects presentation of material and 4.59 for e-book usefulness aspect. Thus, an average score on a one-to-one trial of 4.42 was obtained, which means that the ebook is suitable for learning of the social studies subject. Furthermore, in small group trials conducted on 9 students, the average display aspect values were 4.39 and 4.49 for aspects presentation of material and 4.50 for the e-book usefulness aspect. So, the average obtained 4.46 (very good) and feasible applied to the subjects of social studies. Field trials results show the average value on display aspect of 4.46 and aspects of material presentation 4.61 and 4.59 for aspects of product usefulness. Thus, it can be concluded that the results of oneto-one trials, small group trials, and field trials show the product feasibility criteria in the category of very good and feasible applied for learning social studies seventh-grade junior high school students.

Based on the results of the analysis on social studies learning, it was found that learning social studies especially on historical materials, still rely on lecture methods and using printed books as a source of student learning. Teachers still rarely use instructional media, whereas the use of learning technology can help teachers become creative learning managers and not only share information [5]. Using instructional media will also help improve students' concentration and motivation in learning, as revealed by Sanaky [8] that instructional media is used to facilitate the learning process in the classroom, improve the efficiency of the learning process, maintain relevance between learning materials and learning objectives and help concentration of students in the learning process. Therefore, it made an instructional media in the form of an e-book that is designed according to student needs analysis. Making instructional media that has been adapted to the needs of students will certainly have a more positive impact. Students will be able to feel the benefits and satisfaction of using e-book. As expressed by Joo, Park, and Shin [9], perceptions of usefulness in digital textbooks increase when expectations are met, therefore digital books must be designed to provide useful content and multimedia that help so as to meet the expectations of students.
Expert media validation results obtained 4.67 with a very good category, and the expert material obtained 4.26 with a very good category and the results of user validation shows the value of 4.48 with a very good category. Thus, it can be concluded that the interactive e-book media worthy to be used as a learning resource for learning social studies in seventhgrade junior high school. This e-book can be used as a major learning resource as well as a learning supplement. Varghese, Faith, and Jacob [10] conclude that electronic resources have had a positive impact on various aspects of learning so can be a useful supplement to conventional lecture-based teaching in the medical curriculum. This is also reinforced by research from [11], which states that the use of electronic textbooks is as effective as learning to use traditional textbooks.

\section{CONCLUSION AND SUGGESTION}

The learning process in the current era is required to utilize technology into learning. Students today who are declared as a digital generation feel dissatisfied if doing conventional learning without using technology. Interactive e-book media is designed to provide space for students to use technology in learning and train teachers to become creative learning facilitators. Based on the research results can be concluded that the interactive e-book is designed based on the needs analysis of the use of instructional media in the classroom. The e-book was developed using the ADDIE learning system design procedure, i.e. (1) analysis, (2) design, (3) development, (4) implementation, (5) and evaluation. The results of the feasibility test based on expert validation both experts on media and experts on material and user validation i.e. students indicate that the interactive e-book has a very good quality and deserves to be used as a learning resource to support the learning process of social studies subject for seventh-grade junior high school students.

\section{REFERENCES}

[1] Ministry of Education and Culture, Regulation of the Minister of Education and Culture No.65 on Standard Process of Primary and Secondary Education. Jakarta: Ministry of Education and Culture, 2013.

[2] Musfiqon, Pengembangan Media dan Sumber Pembelajaran [Media Development and Learning Source]. Jakarta: Prestasi Pustaka, 2012.

[3] D. R. Garrison, and N. D. Vaughan, Blended Learning in Higher Education: Frameworks, Principles, and Guidelines. San Francisco: Josey-Bass, 2008.

[4] S. Biagi, Media/Impact: An Introduction to Mass Media, 12th ed., Sacramento: California State University, 2015.

[5] Smaldino, Lowther, and R, Instructional Technology \& Media for Learning. Upper Saddle River, New Jersey: Pearson, 2009.

[6] J. A. Yaya, "Prospects and Challenges of E-Books in School Media Services," in Nigeria: The Way Forward About E-Books, vol. 1, no. 3, pp. 92-98, 2015.

[7] Soenarto, “Konsep Dasar dan Metode Penelitian dan Pengembangan (Research and Development) [Basic Concept and Research and Development Methods],” in Metode Penelitian Pendidikan [Education Research Method], S. I. A. Dwinigrum, Ed., Yogyakarta: UNY Press, 2013, pp. 181-208. 
[8] H. AH. Sanaky, Media Pembelajaran Interaktif - Inovatif [Interactive Inovative Learning Media]. Yogyakarta: Kaukaba Dipantara, 2013.

[9] Y. J. Joo, S. Park, and E. K. Shin, "Students' expectation, satisfaction, and continuance intention to use," Comp. in Hum. Behav., vol. 69, pp. 83-90, 2017.
[10] J. Varghese, M. Faith, and M. Jacob, "Impact of e-resources on learning in biochemistry: first-year medical students’ perceptions,” BMC Med. Edu., pp. 12-21, 2012.

[11] A. J. Szapkiw, J. Courduff, K. Carter, and Bennett, "Electronic versus traditional print textbooks: A comparison study on the influence of university students' learning,” Comp. \& Educ., pp. 259-266, 2013. 